\title{
Honor society membership retention strategies: Promoting membership benefits from induction through transition to professional practice
}

\author{
Emily E. Hopkins, , Meigan Robb, MaryDee Fisher, Julie D. Slade, Jennifer J. Wasco, Kathleen C. Spadaro, Michelle
} Doas

Nursing Department, Chatham University, Pittsburgh, Pennsylvania, United States

Received: March 30, 2016

DOI: $10.5430 /$ jnep.v6n12p18
Accepted: June 6, $2016 \quad$ Online Published: July 18, 2016

URL: http://dx.doi.org/10.5430/jnep.v6n12p18

\begin{abstract}
Being a member of an honor society is a long held tradition for recognition of student academic success. Honor societies have numerous benefits that include not only a level of prestige, but opportunities for continuing education, and networking for professional career advancement. The growth of online learning and education has changed the classroom to a virtual environment where a student's learning achievement may go unrecognized since many honor societies tend to focus on traditional in class students. Recognizing the importance of an honor society and the need for a continued custom to acknowledge student excellence, a small private university in Southwestern Pennsylvania created a virtual nursing honor society that has become a chapter within an international honor society. This honor society chapter encompasses both online and on ground learners. Although a positive asset to students, the chapter has encountered challenges with membership retention after degree completion. Honor society membership retention is possible and enhanced by offering members tangible benefits. Retaining student membership in an honor society can significantly impact professional development as they transition to and grow within nursing practice. This is accomplished through contribution to knowledge development and use of evidence based practice. Therefore, the premise of this article is to share the strategies used by the honor society chapter and identify future recommendations for membership sustainability. The strategies presented in this article are applicable to both new and established honor societies, and professional organizations experiencing membership attrition.
\end{abstract}

Key Words: Honor society, Membership, Retention strategies, Professional practice

\section{INTRODUCTION}

Membership in an honor society is an admirable achievement and academic tradition that brings with it a level of prestige. However, online education has changed the traditional classroom environment and its students-making degree completion possible from a remote location. As such, it is important to recognize and provide an opportunity for honor society membership among all students. With the growth of information technology, offering honor society membership to both on-ground and online distance student populations is possible. More importantly, it is necessary as it provides a way to foster professional development before, during, and after the student transitions into their professional role. Despite the lasting impact an honor society can have on a student, many may choose to decline membership renewal after degree completion. In response to this problem,

\footnotetext{
*Correspondence: Emily E. Hopkins; Email: ehopkins@chatham.edu; Address: Nursing Department, Chatham University, Pittsburgh, Pennsylvania, United States.
} 
the newly recognized online chapter of Sigma Theta Tau International Honor Society of Nursing (STTI) has identified and implemented strategies to bolster membership retention. Therefore, the purpose of this article is to address strategies associated with honor society membership retention.

\section{BACKGROUND}

National and international college honor societies have been around for centuries and were developed with the purpose of recognizing student excellence in academics and promoting leadership, scholarship, service, and research in their members; setting them apart from other societies, fraternities, and clubs on campus. ${ }^{[1]}$ As of 2015, there are 65 nationally certified honor societies from diverse specialties such as business, math, engineering, science, and music, that have varying number of chapters geographically dispersed with total individual society membership ranging from $<1,000$ to $750,000 \cdot{ }^{[2]}$ STTI is among these specialty honor societies and is promoting nursing excellence through more than 485 nursing honor society chapters in 85 countries worldwide, with a total membership $>135,000 .{ }^{[3]}$

Current trends in education show an increase in the number of online educational programs accounting for approximately 6.1 million students as of 2010. ${ }^{[4]}$ With the Institute of Medicine (2011) calling for nurses with higher levels of education, the critical nursing shortage, and the need for baccalaureate prepared nurses to improve patient outcomes, nursing programs have sought to expand educational opportunities. ${ }^{[5,6]}$ Therefore, nursing is one of the educational programs that has experienced a progressive increase in offering of online education with $85 \%$ to $90 \%$ of programs having online courses and $19 \%$ to $35 \%$ having programs entirely online. ${ }^{[7]}$ This exponential growth of online education has created a need to provide access to honor societies among non-traditional distance learners. ${ }^{[8]}$

Like most nursing faculty teaching in undergraduate and graduate academic programs, faculty at a small private university in Southwestern Pennsylvania were members of STTI chapters affiliated with academic institutions through which they received their nursing degrees. However, this university's nursing programs that consisted mostly of online RN to BSN, MSN, and DNP programs did not have its own chapter to acknowledge academic achievement in its students. Having an awareness of the need for online student recognition of excellence as well as a commitment to excellence in nursing education, a small task force of faculty initiated a virtual nursing honor society (vNHS) through their university system and within several years applied for and was granted STTI membership as chapter which conducts most of its activities online. ${ }^{[9]}$

Published by Sciedu Press
As with this chapter, a core issue experienced by most chapters is the burden associated with increasing the size of a membership base through membership retention. ${ }^{[10]}$ Maintaining membership is critical to assist the student with transition to the workforce and continued growth in their professional role. In addition to recognition of outstanding academic student achievement, honor societies provide many member benefits such as further educational enrichment activities, scholarships, networking with peers, employment opportunities, and associations with other professional organizations. ${ }^{[11]}$ Active membership also creates an awareness and a larger perspective about important issues impacting the profession at both an individual practice level and as a collective group of providers. ${ }^{[12]}$ For example, within the nursing profession evidence based practice (EBP) must be consistently implemented when caring for patients. In order to meet this need, STTI has an initiative to be a leader in providing resources for EBP as well as support nursing research and EBP worldwide ${ }^{[13]}$ — demonstrating the importance of honor societies for advancement of professional practice and our nation's health. Furthermore, research indicates that member benefits are far reaching and can have a significant impact on organizational and leadership skill development as well as future education and employment. ${ }^{[14]}$ Based upon society initiatives and previous research findings, the conclusion can be made that there are many benefits to honor society membership which can assist in both professional and personal fulfillment. ${ }^{[15]}$

\section{MeMbeRship RETENTION}

When exploring the concept of member retention it is important to consider what a member wants from the honor society after the excitement of recognition and induction has subsided. Individuals seek membership to chapters for a variety of reasons. Therefore, a single approach for increasing member retention is not plausible. ${ }^{[16]}$ Understanding and responding to member's individual needs is an essential component for encouraging membership renewal. ${ }^{[17]}$ This notion is important for membership growth given that in comparison to veteran members, younger professionals are less likely to renew. ${ }^{[18]}$ Possible reasons lending to this phenomena may be incongruent perceptions of the chapter in relation to the members' characteristics, a poor conceived real dollar value of membership, and lack of personal attention in chapter outreach strategies. ${ }^{[16,17]}$

It is also important to note that not everyone who joins the society has the same initial priorities and values. ${ }^{[16]}$ Reasons for retaining membership with a chapter may evolve during the course of tenure. For example, a student may be honored to have the prestige associated with membership since 
it reflects their academic efforts but over time they may recognize the need for continued membership since it provides access to knowledge and resources useful for professional advancement within their place of employment. Therefore, having distinct current knowledge of what members want and tailoring activities or providing opportunities to meet these needs is vital for membership retention. ${ }^{[16]}$

Previous research supports the idea that membership needs vary based on members' characteristics. Wardell (2003) concluded nurses found memberships beneficial for networking and were very interested in having mentor opportunities as well as teleconference educational offerings. ${ }^{[19]}$ Similarly, Barr (1989) suggested other areas of importance included financial and legal counseling, training and information on how to resolve critical issues, and relevant information on predictions about employment within the profession. There is even a slight indication that some felt membership is part of a professional obligation. ${ }^{[20]}$ Therefore, the inference may be made that members who are more engaged with the chapter may be more likely to renew their membership. ${ }^{[18]}$ However, given that members routinely evaluate the potential return on the dollar - communicating the value in the expense of membership dues is critical for retention. ${ }^{[17]}$ Literature pertaining to the nursing profession indicates that items such as knowledge of member benefits, educational activity opportunities including access to published literature, conferences, and available funding ${ }^{[19,20]}$ were of the utmost importance for membership.

Having some type of personalized communication with members is also important as it allows them to feel valued and appreciated. Thus, creating a continued sense of belonging within the honor society. This strategy may yield fruitful results when implemented to support the renewal of younger professionals in particular. For example, a chapter could routinely send a short society update to members regarding hot topics, reminders about member benefits, or answers to frequently asked questions. Another example would be recognizing when a milestone has been achieved within number of membership year $(1,5,10$, etc.). However, when communicating with members it's important to be flexible and realize that some members may prefer communication other than email. ${ }^{[17]}$ Providing different modes to deliver information reflects that the chapter is conscious of the need to provide personal attention in chapter outreach strategies.

One mode that is growing rapidly and may be useful in creating such strategies is virtual communication through the World Wide Web (WWW). ${ }^{[21]}$ Having a website provides a way to share information at any time-allowing members to stay updated and connected at their convenience. Many professional nursing organizations as well as STTI have successfully tuned into this method of communication for their members. An additional possibility for staying connected is the use of social media. Many professionals including nurses and nursing students are using LinkedIn, Blogs, Facebook, YouTube, and Twitter to as a means to communicate all types of information. ${ }^{[22]}$ Given that a society's top priority is membership retention-leveraging the use of technology while still providing an individual, personal experience requires a delicate balancing act. However, in a fast-paced digital age, members can have real-time interactions, and this ability can immediately increase personal engagement. Ultimately, this immediate capacity to create a feeling of belonging encourages member participation and retention for the future.

\section{Membership Retention Strategies}

Membership retention, although challenging is possible especially when employing current literature based strategies. Further, in order to ensure membership retention and chapter sustainability it is important to continue with current retention strategies as well as consider future retention strategies-using different or new methods as needed. Following this approach will postively support the sustanability of the chapter.

The initial strategy employed was the creation of a chapter webpage housed on STTI's website management system. To ensure a broader access to chapter information, a simple informational page with an overview about the honor society and a link to the chapter website is provided on the university's nursing programs webpage. STTI provides chapter leadership the ability to leverage a pre-designed website as an avenue for communication with its members. The basic features of the website are in use and in January 2015, the chapter was awarded the honor of being STTI's Chapter Website of the Month. The site features include chapter news, upcoming events, and allows for documents and videos to be embedded. An online discussion forum promotes bi-directional communication along with the use of e-Newsletter, an additional core strategy for communicating to the membership. Further, STTI connect is a template electronic newsletter sent to the email address of all active honor society members. This e-newsletter can be customized by chapter leadership on a monthly basis through the online Chapter Management System (CMS) ${ }^{[3]}$ Having these informational offerings through the website provides several avenues to stay informed about important topics that may assist with transition to professional practice.

The STTI main website also provides members direct access to its many offerings and benefits all of which reflect 
member wants and needs which are key for retention as mentioned in the literature reviewed. These offerings include but are not limited to the following: specialty leadership academies, research awards, excellence awards, scholarships, research grants, electronic communication (including Twitter and Facebook), and international conferences, opportunities to build a scholarly agenda through poster and podium presentations, STTI publications, and volunteer opportunities. Benefits include a cash rewards credit card, access to a free online evidence based practice repository, discounts on $\mathrm{Wi}$ ley publications, discounts on liability insurance, a career center with advisors and connections to assist with professional portfolio management and more than 36 continuing education credit hours at no charge. ${ }^{[3,23]}$ Clearly, these benefits provide many opportunities for continued professional growth and development.

Although overall STTI member benefits are far reaching, there is still a need to attract and retain members within each individual chapter. Recognizing the importance of meeting member needs for retention led the university's chapter to provide several attractive opportunities that ac- tively promote participation as well as demonstrate appreciation of their membership (see Table 1). In an effort to retain members, an attempt was made to create a community made up of, and run by, its members. The chapter currently has three running subcommittees: the Governance Committee, the Leadership Succession Committee, and the Scholarship/Education/Technology (SET) Committee. All members are welcomed and encouraged to be an active committee member and help form the chapter to meet their needs. For members who choose to not be involved on a committee a myriad of events are hosted to attempt to meet the needs of members locally and on a national level. Some of these activities included recorded induction ceremonies that could be viewed in a remote asynchronous fashion and featured a speaker who is a nursing leader, an online journal club, virtual poster sessions, live speakers and documentary viewing, toolkits to assist with membership scholarship, website communication, and t-shirt sales to help create a sense of community belonging. Additionally, these committees and events all provide opportunities to assist members with professional practice transition through networking and mentorship.

Table 1. STTI Chapter Retention Strategies and Associated Member Benefits

\begin{tabular}{|c|c|c|}
\hline Current Retention Strategies & STTI Chapter Examples & Member Benefits \\
\hline \multirow{3}{*}{$\begin{array}{l}\text { Committee Membership } \\
\text { opportunities }\end{array}$} & Governance & $\begin{array}{l}\text { Influence Chapter oversight and activities } \\
\text { supporting STTI vision }\end{array}$ \\
\hline & Leadership Succession & $\begin{array}{l}\text { Identify members to mentor for potential } \\
\text { (leadership) board and/or chairperson } \\
\text { positions }\end{array}$ \\
\hline & Scholarship/Education/Technology (SET) & $\begin{array}{l}\text { Outline areas of focus for formal Chapter } \\
\text { offerings }\end{array}$ \\
\hline Virtual Ceremonies & Chartering and Annual Inductions & $\begin{array}{l}\text { Afford remote and asynchronous viewing } \\
\text { Nationally/Internationally }\end{array}$ \\
\hline $\begin{array}{l}\text { Induction Ceremony Speakers } \\
\text { selection }\end{array}$ & Alumni and leaders in profession & $\begin{array}{l}\text { Deliver inspiring message from rising } \\
\text { nursing leaders }\end{array}$ \\
\hline Online journal club & Cognitive Aids & Promote safer EBP patient care \& outcomes \\
\hline Tool Kits & $\begin{array}{l}\text { Narrated Power Point directing members on } \\
\text { creation of scholarly poster available in Chapter } \\
\text { Resource Library }\end{array}$ & $\begin{array}{l}\text { Offer opportunity to acquire scholarly } \\
\text { strategies from fellow chapter members }\end{array}$ \\
\hline Virtual Poster Session & $\begin{array}{l}\text { Online poster session presented for exploration } \\
\text { by chapter members }\end{array}$ & $\begin{array}{l}\text { Encourage confidence for and competence } \\
\text { in scholarship of dissemination }\end{array}$ \\
\hline On-Campus events & $\begin{array}{l}\text { The American Nurse documentary } \\
\text { Mental Health Symposium }\end{array}$ & $\begin{array}{l}\text { Provide engaging opportunities for increased } \\
\text { awareness of professional issues; CEUs }\end{array}$ \\
\hline Fund raisers & T-shirts and flower bulbs via online ordering & Cultivate sense of community \\
\hline
\end{tabular}

Current membership retention and future sustainability

By implementing these strategies, the small private university of Southwestern Pennsylvania's STTI chapter has had great success with membership retention increasing from a retention rate of $39 \%$ among 2014 inductees to a retention

Published by Sciedu Press

rate of $95 \%$ among 2015 inductees. This chapter has also retained $80 \%$ of members who have transferred membership from other STTI chapters. These current retention rates surpass STTI's general retention rate of approximately $70 \%$. $^{\text {[24] }}$ Further, there has been a substantial $257 \%$ growth in over- 
all membership from 2014-2016. This growth has brought about a diverse group of members that possess strong leadership skills noted by the 2016 elections for president, vice president, counselor governance chair, web master, treasurer, and convention delegates all being filled by student alumni rather than university nursing faculty.

However, in order to maintain and continue to grow honor society membership, several future retention strategies and their member benefits have been identified and are provided in Table 2. In addition, given the online basis of this STTI chapter it is essential to develop solid operational information technology resources to achieve desired sustainability. This strategy needs to include a robust information technology plan with a primary focus on creating a social media campaign that will support the needs of members as they transition from student to professional practice. There is also a necessity to further evaluate what types of communication members prefer from the chapter as members continue to grow and develop as professionals.

Table 2. Future STTI Retention Strategies and Member Benefits

\begin{tabular}{|c|c|}
\hline Future Retention Strategies & Potential Member Benefits \\
\hline Survey of members & $\begin{array}{ll}- & \text { Provide feedback for chapter direction } \\
\text { - } & \text { Promote sense of ownership by influencing Chapter activities and governance } \\
\text { oversight }\end{array}$ \\
\hline $\begin{array}{l}\text { Secure closed section of social media } \\
\text { platform }\end{array}$ & $\begin{array}{ll}\text { - } & \text { Create sense of community } \\
\text { - } & \text { Promote socialization among members } \\
\text { - } & \text { Engage members in exchange of ideas to foster lifelong leaning }\end{array}$ \\
\hline $\begin{array}{l}\text { Dedicate Scholarship notes corner on } \\
\text { Chapter website }\end{array}$ & $\begin{array}{l}\text { - Provide opportunity to highlight many types of scholarly achievements and } \\
\text { facilitate member collaboration }\end{array}$ \\
\hline $\begin{array}{l}\text { Create member YouTube channel to } \\
\text { post "pre-made" videos }\end{array}$ & - $\quad$ Provide resources in efficient fashion to impact health of populations \\
\hline $\begin{array}{l}\text { Host social event prior to graduation } \\
\text { ceremonies }\end{array}$ & - $\quad$ Strengthen sense of community and member commitment \\
\hline Partner with local Chapter & - $\quad$ Offer opportunity to collaborate with other scholars \\
\hline
\end{tabular}

\section{RECOMMENDATIONS}

Although retention is challenging, as demonstrated by this STTI chapter's success-simple strategies can be used that may have a significant impact. Especially when they pro- vide a sense of belonging and appreciation to members. The strategies presented previously are applicable to both new and established honor societies as well as professional organizations experiencing membership attrition. Table 3 provides a summary of recommended key strategies for retention.

Table 3. Recommendations for Retention Strategies

\begin{tabular}{|ll|}
\hline Points to Consider for Retention \\
- & Create an awareness about the benefits and monetary value of membership \\
- & Provide brief but meaningful updates about the society \\
- & Use multiples modes of communication \\
- & Engage members through annual conferences \\
- & Communicate through social media that is favored by members \\
- & Provide personalized communication that makes members feel appreciated \\
\hline
\end{tabular}

\section{Conclusion}

An honor society not only signifies excellence among accomplished students, it provides valuable opportunities to those with continued membership as well. These opportunities include benefits such as networking, grant funding, employment, continuing education, and evidence based practice knowledge and resources. As a result, honor societies play 
an important role in preparing the novice nurse transitioning to professional practice-possibly leading to improved patient outcomes. In order to attract and retain members, it is of the utmost importance for the society to communicate clearly and effectively, creating an awareness of membership benefits as well as determining what member needs are. With an immense and rapid influx of various types of technology being introduced to the electronic world on a daily basis, it is essential the chapter leadership stay informed of innovative methods in which to connect with their mem- bers. Having an effective connection that makes members feel valued in addition to developing activities that are purposeful, interesting, and attractive are vital for membership retention. When implemented at a small private university in Southwestern Pennsylvania, these shared strategies and recommendations yeilded significant results for membership retention and growth -demonstrating their effectiveness.

\section{CONFLicts OF INTEREST Disclosure}

The authors declare that they have no competing interests.

\section{REFERENCES}

[1] Phi Beta Kappa. The nation's oldest and most widely known academic honor society. [Internet] WashingtonDC: The Phi Beta Kappa Society [cited 2016 Feb 29] Available from: https : //www . pbk. org/WEB/PBK_Member/About_PBK/PBK_Member/About_ --_. aspx?hkey=7b14c826-1a07-4148-a627-2c1a6b1ed3a6

[2] ACHS: membership directory [Internet] Okemos: Association of College Honor Societies; c2015 [cited 2016 January 16]. Available from: http://www.achsnatl.org/membership.asp

[3] STTI Organizational Fact Sheet [Internet] Indianapolis: Sigma Theta Tau International Honor Society of Nursing; c2016 [cited 2016 Feb 29]. Available from: http://www.nursingsociety.org/why-s tti/about-stti/sigma-theta-tau-international-organ izational-fact-sheet

[4] Allen IE, Seaman J. Changing Course: Ten years of tracking online education in the United States. [Internet]. Babson Research Survey Group; c2013 [cited 2016 Feb 29]. Available from: http: //www. on linelearningsurvey. com/reports/changingcourse.pdf

[5] IOM: The future of nursing: Leading change, advancing health. [Internet] Washington DC: National Academy of Sciences; c2016 [cited 2016 Mar 8]. Available from: https: //iom.nationalacademies.org/Reports/2010/The-Futur e-of-Nursing-Leading-Change-Advancing-Health . aspx

[6] Rosseter R. Nursing faculty shortage [Internet] Washington DC: American Association of Colleges of Nursing; c 2015 [cited 2016 Mar 9]. Available from: http://www . aacn.nche.edu/media-r elations/fact-sheets/nursing-faculty-shortage

[7] Fang D, Li Y, Bednash GD. 2012-2013 Enrollment and Graduations in Baccalaureate and Graduate Programs in Nursing. [Internet] Washington, DC: American Association of Colleges of Nursing; c2013. [cited 2016 Mar 9] Available from: http://www.aacn.nch e.edu/downloads/ids/2013/EG12.pdf

[8] McFarlane DA. The leadership roles of distance learning administrators (DLAs) in increasing educational value and quality perceptions. Online Journal of Distance Learning Administration [Internet]. 2011 Sping [cited 2016 Mar 9]; IV(1) Available from: http: //www . west ga.edu/ distance/ojdla/spring141/McFarlane141.html

[9] Spadaro KC, Stevens EE, Doas M, et al. A virtual nursing honor society: Recognition for online academic excellence. Journal of Nursing Education and Practice. 2014 Jan; 4(3): 197-203. http: //dx.doi.org/10.5430/jnep.v4n3p197

[10] Leading globally: address by the 27th President Honor Society of Nursing, Sigma Theta Tau International. West African Journal of Nursing. 2008 Nov; 19(2): 153-157.

[11] ACHS: a matter of honor [Internet] Okemos: Association of College Honor Societies; c2016 [cited 2016 February 16]. Available from: http://www.achsnatl.org/achsbene.asp
[12] Frank K. Benefits of Professional nursing organization membership. AORN Journal. 2005 Jul; 82(1): 13-14. http://dx . doi .org/10. 1016/S0001-2092(06)60291-3

[13] Honor society study shows majority of nurses rely on evidence-based practice. Prairie Rose. 2006 Nov-2007 Jan; 75(4): 11-11.

[14] Ferrari JR, Athey RB, Moriarty MO, et al. Education and employment among alumni academic honor society leaders. Education. 2006; 127(2): 244-259.

[15] Schroeder RT. The value of belonging to a professional nursing organization. AORN Journal. 2013 Aug; 98(2): 99-101. PMid:23890558 http://dx.doi.org/10.1016/j.aorn.2013.06.002

[16] Seibert L. What Members Value in Their Decision to Join or Renew Their Association Membership; [Internet] ASAE The Center for Association Leadership; c2008 [cited 2016 Feb 15] Available from: https://www. asaecenter.org/en

[17] Metter K. Nitty gritty member retention [Internet]. ASAE The Center for Association Leadership; c2002 [cited 2016 Feb 15] Available from: https://www. asaecenter.org/en

[18] Markova G, Ford R, Dickson D, et al. Professional Associations and Member Benefits: What's in it for me? Nonprofit Management \& Leadership. 2013 Summer; 2(4): 491-510. http://dx.doi .org/1 $0.1002 / \mathrm{nml} .21076$

[19] Wardell L, White C, Fitzgerald G. Professional nursing organizations: what nurses want. AXON/ L'AXONE. 2003 Dec; 25(2): 8-9.

[20] Barr PB, Balsmeier PW, Dave DS. Recruitment and retention in a professional nursing organization. The Mississippi RB. 1989 Jul-Aug; 51(4): 10-22.

[21] National Council of State Boards of Nursing. White paper: A nurse's guide to the use of social media. Indiana Nurse. 2014 Nov, Dec, Jan: $12-15$.

[22] Ferguson C. It's time for the nursing profession to leverage social media. J Adv Nurs. 2013 Jan; 69(4): 745-747. PMid:23488814 http://dx.doi.org/10.1111/jan.12036

[23] STTI Member Benefits and Resources [Internet] Indianapolis: Sigma Theta Tau International Honor Society of Nursing; 2016 [cited 2016 Feb 29]. Available from: http://www. nursingsociety.org/why-stti/stti-mem bership/stti-member-benefits-and-resources

[24] STTI Honor Society Membership Renewal Process [Internet] Indianapolis: Sigma Theta Tau International Honor Society of Nursing; c2016 [cited 2016 May 27]. Available from: http://www. nursingsociety.org/connect-engage/chap ters/starting-an-sttichapter/honor-society-members hip-renewal-process 